\title{
Leukoderma and chronic inflammatory demyelinating polyradiculoneuropathy in an adolescent with graft-versus-host disease
}

\author{
Graft-versus-host hastalığı olan bir ergende lökoderma ve kronik inflamatuar demiyelinizan \\ poliradikülonöropati birlikteliği
}

Gökhan OKAN, Fatih ERBEY, Mehmet Sait DURMUŞ, Gülyüz Hanife ÖZTÜRK

\begin{abstract}
A 15-year-old Iraqi male patient with acute lymphoblastic leukemia received an allogeneic bone marrow transplant from his brother. On the 18th day after the transplant, the patient developed grade II acute graft-versus-host disease, and treatment included methylprednisolone. On day 140, the patient was diagnosed with leukoderma. On day 150, the patient was admitted to hospital because of numbness and muscle weakness in the extremities and a disturbance of the gait. Neurologic examination showed muscle weakness in the upper and lower extremities and there were no deep tendon reflexes. Nerve conduction studies showed reduced conduction speeds of the motor nerves with demyelinating features. The patient was diagnosed as having a chronic inflammatory demyelinating polyradiculoneuropathy (CIDB) based on clinical and electrophysiological findings. Treatment included methylprednisolone and intravenous immunoglobulin. The neurologic function improved but the skin lesions persisted. This case shows that graft-versus-host disease can act as a triggering factor for the appearance of autoimmune diseases.
\end{abstract}

Keywords: Leukemia, Graft-versus-host disease, Leukoderma, Chronic inflammatory demyelinating polyneuropathy

\section{ÖZET}

Akut lenfoblastik lösemisi olan 15 yaşındaki Iraklı erkek hastaya ağabeyinden allojenik kemik iliği nakli yapıldı. Nakilden 18 gün

Gökhan Okan (西)

Dermatology Clinic, Medical Park Bahçelievler Hospital, Istanbul, Turkey m-mail.gokhanokan8@hotmail.com

Fatih Erbey, Mehmet Sait Durmuş

Bone Marrow Transplantation Unit, Medical Park Bahçelievler Hospital, Istanbul, Turkey

Gülyüz Hanife Öztürk

Bone Marrow Transplantation Unit, Istanbul Medical Faculty, Istanbul University, Istanbul, Turkey

Submitted/Gönderilme: 13.12 .2014

Accepted/Kabul: 21.02.2015 sonra hastada evre 2 graft-versus-host hastalığ gelişti ve tedavi olarak metilprednizolon verildi. 140. günde hastaya lökoderma tanıs1 konuldu. 150. günde hasta ekstremitelerde uyuşma, kas güçsüzlüğü ve denge bozukluğu nedeniyle başvurdu. Nörolojik muayenede üst ve alt ekstremitelerde kas zayıflığ görüldü ve tüm derin tendon refleksleri yoktu. Sinir iletim testleri gecikmiş motor sinir iletimini gösterdi. Hastaya kronik inflamatuar demiyelinizan poliradikülonöropati tanısı klinik ve elektrofizyolojik bulgulara dayanılarak konuldu. Tedavi olarak metilprednizolon ve intravenöz immunglobulin verildi. Nörolojik fonksiyonları düzeldi fakat cilt bulguları devam etti. Bu vaka graft-versus-host hastalığının otoimmun hastalıkların ortaya çıkması için tetikleyici bir faktör olabileceğini göstermektedir.

Anahtar kelimeler: Lösemi, Graft-versus-host hastalığ1, Lökoderma, Kronikinflamatuardemiyelinizan poliradikülonöropati

\section{Introduction}

Chronic graft-versus-host disease (GVHD) is a systemic multiorgan syndrome that occurs in $25 \%$ to $50 \%$ of long term hematopoietic cell transplant survivors. Risk factors for chronic GVHD include previous acute GVHD, older patient ages, the use of female donors for male recipients, donor lymphocyte infusions, unrelated or human leukocyte antigen-mismatched donors, and the peripheral blood as a source of stem cells [1,2]. GVHD can also occur after a blood transfusion if the blood used has not been irradiated [3].

The presentation of chronic GVHD may be progressive, quiescent, or de novo late onset. Skin is the most commonly affected organ in chronic GVHD, and diagnostic skin manifestations of GVHD include poikiloderma, lichen planus-like eruptions, lichen sclerosus-like lesions, morphealike sclerosis, and deep sclerosis and fasciitis. Vitiligo is not a common complication of GVHD. Additional sites of involvement of GVHD include the mouth, eyes, liver, lungs, 
bone marrow, and vulvovaginal region, and manifestations may include esophagal webs and strictures, myositis, nephrotic syndrome, pericarditis, peripheral neuropathy, and myasthenia gravis [4].

We treated an adolescent male patient who had Philadelphia chromosome-positive acute lymphoblastic leukemia. After an allogeneic stem cell transplant, he developed leukoderma and chronic inflammatory demyelinating polyradiculoneuropathy (CIDP).

\section{Case Report}

A 15-year-old Iraqi male patient in the first remission of Philadelphia chromosome-positive acute lymphoblastic leukemia received an allogeneic bone marrow transplant from a human leukocyte antigen-matched sibling donor, his brother. The patient and brother had no history of depigmentary dermatoses. The conditioning regimen included busulfan and cyclophosphamide, and cyclosporine A was used as prophylaxis against GVHD.

On day 18 after the transplant, the patient developed grade II acute GVHD with skin involvement. The patient complained of skin rashes and dryness. Methylprednisolone $(2 \mathrm{mg} / \mathrm{kg} / \mathrm{d}$ ) was added, tapered after control of the GVHD, and stopped on day 41 . His symptoms and signs disappeared by this therapy. On day 100 , he developed renal tubular dysfunction related to cyclosporine A; the cyclosporine A was stopped and mycophenolate mofetil was started.

On day 140, the patient began to develop depigmented patches on the face, chest, trunk, and extremities. He was diagnosed with leukoderma (Figures 1a, b). He was given tacrolimus $0.1 \%$ and triamcinolone ointment to apply on the affected areas twice daily. On day 150, the patient was admitted to hospital because of a two day history of sensory disturbaces, gait disturbance and muscle weakness in both lower and upper extremities. Neurologic examination showed muscle weakness in the upper extremties (strength, 3/6) and lower extremities (strength, 2/6). There were no deep tendon reflexes. Autonomic nervous system, cranial nerve, and respiratory functions were normal. Cranial and spinal cord magnetic resonance imaging scans were normal. The cerebrospinal fluid had a protein level $27.8 \mathrm{mg} /$ $\mathrm{dL}$ and contained no cells. There were oligoclonal bands detected in the cerebrospinal fluid or serum. Laboratory evaluation was negative for human immunodeficiency virus, cytomegalovirus, syphilis, viral hepatitis, and autoimmune disorders. Nerve conduction studies revealed a slow motor nerve conduction velocity with a low compound muscle action potential amplitude in the upper and lower extremities.
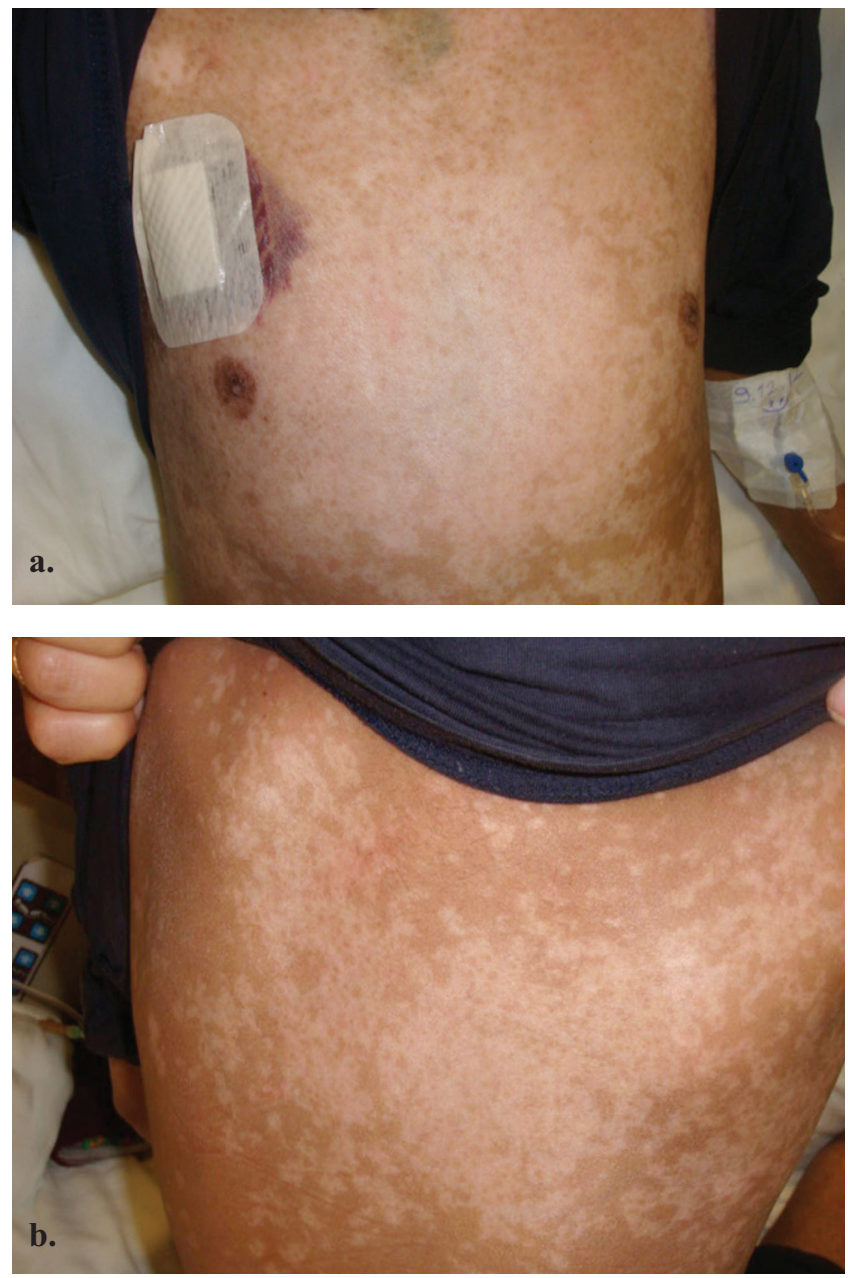

Figure a,b: A-15-year-old male who had Philadelphia chromosome-positive acute lymphoblastic leukemia, developed leukoderma after an allogeneic bone marrow transplant. The (a) chest and (b) back had multiple white, depigmented, sharplydefined skin lesions consistent with leukoderma.

The patient was diagnosed with CIDB based on clinical and electrophysiological findings. Treatment included methylprednisolone (1 $\mathrm{mg} / \mathrm{kg} / \mathrm{d}$ intravenous) and intravenous immunoglobulin (400 $\mathrm{mg} / \mathrm{kg} / \mathrm{d}$ for $5 \mathrm{~d}$ ). Mycophenolate mofetil was continued and sirolimus was started. Within 6 weeks after beginning this therapy, there was improvement of the muscle weakness(upper extremities $6 / 6$, lower extremities 5/6) and gait, and the deep tendon reflexes became normal. In spite of topical steroids and topical tacrolimus, the patient had persistent areas of depigmentation on the face, chest, trunk, and extremities. Psoralen and ultraviolet A treatment were not given to the patient because of his compromised health status. During three months of the follow-up period, depigmentation did not spread. 


\section{Discussion}

The present patient had a clinical presentation consistent with progressive GVHD, with gradual progression from acute to chronic GVHD. This was complicated by leukoderma and chronic inflammatory demyelinating polyradiculoneuropathy.

The present patient had the clinical appearance of generalized leukoderma. Neither the patient nor the donor had a history of depigmentary dermatoses. Treatment with cyclosporine A for GVHD prophylaxis may have delayed the onset of leukoderma in the patient. The GVHD may trigger autoimmune diseases in patients who have a genetic predisposition to autoimmune disorders. Patients with GVHD have a high incidence of detectable autoantibodies (including antinuclear, double-stranded DNA and smoothmuscle antibodies) and disease-related gene polymorphisms common to patients with autoimmune disorders [5]. Pathogenesis of developing vitiligo in GVHD is due to increased TNF- $\alpha$ production [6]. Elevated levels of TNF- $\alpha$ and IL- 6 have been found in vitiligous skin compared to adjacent uninvolved skin. It has been suggested that chronic GVHD may be induced by synergistic interaction of IL-6 and TNF- $\alpha$ [7]. Leukoderma associated with GVHD usually shows limited clinical improvement. Tan et al. reported a case of stable leucoderma associated with chronic graftversus-host disease that achieved repigmentation following autologous noncultured cellular transplantation [8].

CIDP is a chronic, acquired, immune mediated condition affecting the peripheral nerves. The diagnosis of this neuropathy can be established by clinical and electromyographic criteria. Nerve biopsy is less often required [9]. It is an important complication, and $0.6 \%$ to $4 \%$ patients develop peripheral neuropathy after an allogeneic stem cell transplant $[10,11]$. The pathogenesis of CIDP associated with GVHD may include the development of nerve demyelination and inflammation secondary to immune-mediated effects. This may include cell and antibody mediated immune responses to glycolipid or myelin protein antigens.

CIDP typically has an onset of $>90$ days after allogeneic stem cell transplant. Clinical and neurophysiological findings can be the same for CIDP and Guillian-Barre syndrome (GBS). CIDP symptoms tend to come on more slowly and progress for a longer period of time. The distinction between CDIB and GBS is also based on the time to maximal neurological deficit. For GBS this is 4 weeks and more than 8 weeks is classifed as CIDB[12]. This polyradiculoneuropathy may have a progressive course, with poor response to medical treatment. Improvement may occur in $50 \%$ to $80 \%$ patients, usually within a few weeks of treatment. In the present patient, the polyradiculoneuropathy was controlled with methylprednisolone, intravenous immunoglobulin for 5 days, mycophenolate mofetil, and sirolimus, and no further intravenous immunoglobulin infusions were necessary. After treatment for polyradiculoneuropathy, the depigmented lesions did not improve or spread.

Chronic inflammatory demyelinating polyradiculoneuropathy may be associated with several autoimmune conditions. Furthermore, a previous study described a patient who had chronic inflammatory demyelinating polyradiculoneuropathy with melanoma and vitiligo [13]. However, the association of chronic inflammatory demyelinating polyradiculoneuropathy with vitiligo is rare. Though the coexistence of these two diseases in the same patient could be merely coincidental, the proposed autoimmune nature of both diseases might suggest a relationship between them. Melanocytes and Schwann cells are derived from the neural crest, share potential surface antigens including MAG [14] and gangliosides (GM2, GM3, GD3, GD2) [15] and thus may share common antigenic components with peripheral nerve. Although we did not detect anti-MAG or anti-GM1 antibodies, the possibility of antibodies directed against a common antigen is intriguing and shared immunoreactivity may have accounted for the association between leukoderma and chronic inflammatory demyelinating polyradiculoneuropathy in our patient.

\section{References}

1. Filipovich $\mathrm{AH}$, Weisdorf $\mathrm{D}$, Pavletic $\mathrm{S}$, et al. National Institutes of Health consensus development project on criteria for clinical trials in chronic graft-versus-host disease: I. Diagnosis and staging working group report. Biol Blood Marrow Transplant 2005;11:945-56.

2. Tran K, Kaplan J, Kamino H, Latkowski J-A. Graft-vs-host disease. Dermatol Online J 2013 ; 19: 20710.

3. Batırel A, Özer S, Gençer S, et al. İmmunkompetan bir hastada ortopedik cerrahi sonrası gelişen transfüzyonla ilişkili graft versus host hastalı̆̆1. Marmara Med J 2006; 19:36-40.

4. Hymes SR, Alousi AM, Cowen EW. Graft-versus-host disease: part I. Pathogenesis and clinical manifestations of graft-versus-host disease. J Am Acad Dermatol 2012;66:515. e1-e18.doi: 10.1016/j.jaad.2011.11.960

5. Shimada M, Onizuka M, Machida S, et al. Association of autoimmune disease-related gene polymorphisms with chronic graft-versus-host disease. Br J Haematol 2007; 139: 458-63.

6. Kang HY, Kang WH. Leukomelanoderma following acute cutaneous graft-versus-host disease. Eur J Dermatol 2004; 14 : 
$146-9$.

7. Imamura M, Hashino S, Kobayashi H, et al. Serum cytokine levels in bone marrow transplantation: synergic interaction of interleukin-6, interferon-gamma and tumor necrosis factoralpha in graft versus-host disease. Bone Marrow Transplant 1994; 13: 745-51.

8. Tan AW, Koh LP, Goh BK. Leucoderma in chronic graft-versus-host disease: excellent repigmentation with noncultured cellular grafting. Br J Dermatol 2011 ; 165: 43537. doi: 10.1111/j.1365-2133.2011.10341

9. Van den Bergh PY, Hadden RD, Bouche P, et al. European Federation of Neurological Societies/Peripheral Nerve Society Guideline on management of chronic inflammatory demyelinating polyradiculoneuropathy: Report of a joint task force of the European Federation of Neurological Societies and the Peripheral Nerve Society - First Revision. Eur J Neurol 2010; 17: 356-63. doi: 10.1111/j.1468-1331.2009.02930

10. Lorenzoni PJ, Scola RH, Carsten AL, et al. Chronic inflammatory demyelinating polyradiculoneuropathy in chronic graft-versus-host disease following allogeneic hematopoietic stem cell transplantation: case report. Arq Neuropsiquiatr $2007 ; 65: 700-4$

11. Doi Y, Sugahara H, Yamamoto K, et al. Immune-mediated peripheral neuropathy occurring simultaneously with recurrent graft-versus-host disease after allogenic hematopoietic stem cell transplantation. Leuk Res. 2012 ;36:e63-5. doi: 10.1016/j. leukres.2011.11.025.Epub 2011 Dec 17.

12. Gorson KC. An update on the management of chronic inflammatory demyelinating polyneuropathy. Ther Adv Neurol Disord 2012; 5: 359-73.

doi: $10.1177 / 1756285612457215$

13. Bird SJ, Brown MJ, Shy ME, et al. Chronic inflammatory demyelinating polyneuropathy associated with malignant melanoma. Neurology 1996 ; 46:822-4.

14. Noronha AB, Harper JR, Ilyas AA, et al. Myelin-associated glycoprotein shares an antigenic determinant with a glycoprotein of human melanoma cells. J Neurochem 1986 ; 47:1558-65.

15. Tsuchida T, Saxton RE, Morton DL, et al. Gangliosides of human melanoma. Cancer 1989; 63:1166-74. 